\title{
The Role of Women in Fish Production A Case Study of Igbokoda Local Government Area Ondo State, Nigeria
}

\author{
Sodamola MO*, Apiakason E, Odejide JO, Adejola YA and Anichie D \\ Federal College of Agriculture P.M.B, Moor Plantation Ibadan Oyo State, Nigeria \\ *Corresponding Author: Sodamola MO, Federal College of Agriculture P.M.B, Moor Plantation Ibadan Oyo State, Nigeria.
}

Received: July 10, 2019; Published: August 09, 2019

DOI: 10.31080/ASNH.2019.03.0402

\begin{abstract}
The study of role of women in fish production at Igbokoda Local Government Area of Ondo State was carried out using questionnaire and personal interview on a randomly selected women involved in fishing activities. One hundred questionnaires were administered but seventy-three were recovered. The result revealed that women are involved in all the fishing activities like catching, preserving and marketing in fishing right from youth (25 years and above) and fishing is a major business or source of income. Majority of the respondent were married (54\%) a situation which prevented changing of work. The result also showed that fishing is not the only vocation, women were also involved in other fishing activities like net making, basket weaving and they also belong to fish cooperative societies that see to the improvement of the society and betterment of their family at large. Histogram and Regression were run to analysis the result.
\end{abstract}

Keywords: Igbokoda; Fish

\section{Introduction}

Fish is a possible food item in Africa and it plays an important role as a major contributor to animal protein supplies and a good foreign exchange earner USD197,359 FAO [1]. It is an important source of animal protein for a wider spectrum of the Nigeria population Based on the information the fourth National Development Plan (1980 - 85), 40\% of animal protein consumed by the average Nigerian comes from fish. FAO [2] stated that the average per catput consumption of fish per day should be $24.26 \mathrm{~g}$, which is part of $38 \%$ of ingested protein. Fish is highly palatable and nutritionists have found that the flesh is a "first class protein" composed of about the same type of amino acids as those of human beings and therefore move than any other protein of animal origin.

In Nigeria and most third world countries an emergency view of development is one of which the government must satisfy basic human needs, and at the same time foster economic growth.
Thus, the total number of full time, part time and seasonal fishermen on the continent is about 1.9 million of whom $98 \%$ operates in the artisanal sector of processing and distribution where women are mostly involved is thought to increase the number of people involved in Artisanal fisheries to nearly 10 million Tvedten and Hersoug [3] was reported by Oyegbola [4]. In many countries of the world, both developed and developing, women have always had substantial input in the decision making process to varying degree and indeed they manage farms with their husband making overall policy decision to be add by Dilion and Hardaker [5]. In most societies of the world, the socio-cultural position of woman has an important normative influence in allocating occupational roles to them. Generally, women involvement in fish activities (catching) is pronounced as well as their involvement in the secondary sector such as processing and distribution. The bulk of the work of fishes handled by women, they perform the function of auctioneers, retailer, fish vendors and dealers of export Fagade [6]. 
Women involved in fishing are generally referred to as "Mammy". Those women (Fish mongers can either market fresh or processed fish. They also do the sorting, washing, grading and distributing to buyers. The role of women also include processing of the fish if landing were not immediately disposed by methods of salting, sun drying, freezing or smoking for the need of developing countries like Nigeria Amos [7].

\section{Methodology}

Study area

The study was carried out in Igbokoda Local Government Area in Ondo State where the main occupation of the people is fishing.

The local government Igbokoda in Ondo State is located between longitude $4^{\circ} 20.3^{1 \mathrm{E}}$ and $5^{\circ} 08^{1 \mathrm{E}}$ of the prime meridian and $5^{\circ} 58^{1 \mathrm{~N}}$ and $6^{\circ} 29^{\mathrm{N}}$ of the equator. The local government is bounded in North by Ikale and South by Atlantic ocean with a coast line of 80 $\mathrm{km}$ long. This makes Ondo State one of fish producing state Mogbojuri [8]. The major means of transportation in the study area are motorised canoes, speed boat and padded canoes. Most of the houses are built on elevated platform above water level. The area has two seasons in the year. Dry and rainy seasons which are usually prolonged Mogbojuri [8].

Sampling and sample size

In Igbokoda local government there are about 6 wards/zones. There is a common place which was selected where all the women involved in fishing business normal assemble, one hundred questionnaires were distributed but only seventy-three respondents were recovered.

\section{Data collection}

The administration of a provisional questionnaire was given by direct distribution to the respondents out of the one hundred questionnaires distributed seventy-three were recovered through the help of the enumerators. Enumerators are people who are conversant with the local language and customs of the people.

\section{Data analyis}

Data collected form the respondents were analysed and presented on the basis of the responses given. In the calculations of the result all number were applicable and were convincingly rounded off to one significant figure after decimal points.

\section{Results and Discussion}

Women in the study area from the data are analysis into demographic factor or the socio-economic characteristics which include the age, marital status and education. The figure 1 shows that $41 \%$ of the respondents were between 20 -30 years while $32 \%$ were between $31-40$ years. However, $41-50$ years are about $19 \%$ but $8 \%$ were between 51 years above. These shows that women are always involved in fish even from the young age to old age.

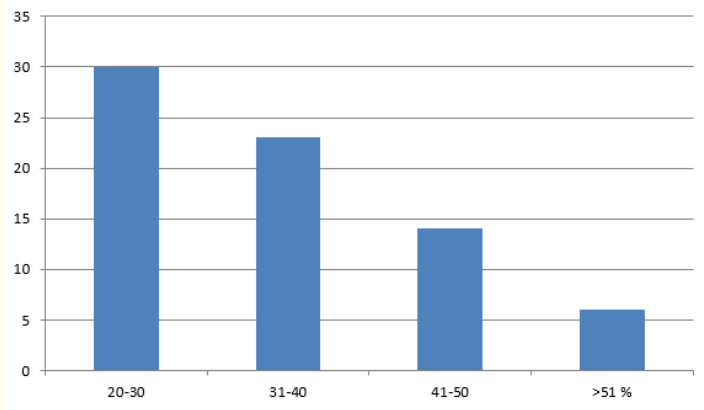

Figure 1: Frequency Distribution of Age Group of women in the study.

\begin{tabular}{|l|c|c|}
\hline Age & Frequency & Percentage \\
\hline 20 - 30 years & 30 & 41 \\
31 - 40 years & 23 & 32 \\
41 - 50 years & 14 & 19 \\
51 and above & 6 & 8 \\
\hline Total & 73 & 100 \\
\hline
\end{tabular}

Table 1: Age group of women in the study area.

Table 2 shows that twenty one percent $(21 \%)$ of the women in the study are single while fifty four percent (54\%) are married. The effect of this is that a high population of married women in the study area are permanent settler sand migration is not a regular occurrence in the area and all their business activities revolve round the area.

\begin{tabular}{|l|c|c|}
\hline Marital Status & Frequency & Percentage \\
\hline Single & 15 & 21 \\
Married & 39 & 54 \\
Divorced & 7 & 9 \\
widowed & 12 & 16 \\
\hline Total & 73 & 100 \\
\hline
\end{tabular}

Table 2: Marital status of women involved in fishing activities in the study area. 


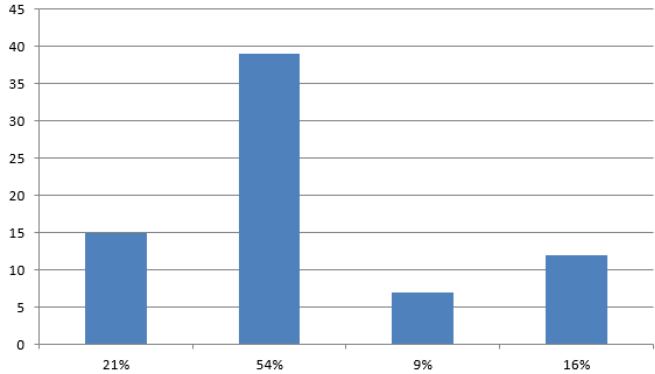

Figure 2: Frequency Distribution of marital status of the women.

Table 3 Educational level of respondents from the study, $48 \%$ have not received any form of education, about $42 \%$ attended primary school from the above result could be attributed to the fact that most of that people in the area of study are traditionally fisher women hence after primary education they introduce their wards to full scale fishing business and even the young ones.

\begin{tabular}{|l|c|c|}
\hline Highest Educational level & Frequency & Percentage \\
\hline No formal Education & 35 & 48 \\
Primary School & 31 & 42 \\
Modern/Secondary school & 7 & 10 \\
Tertiary & - & - \\
\hline Total & 73 & 100 \\
\hline
\end{tabular}

Table 3: Educational level of respondents.

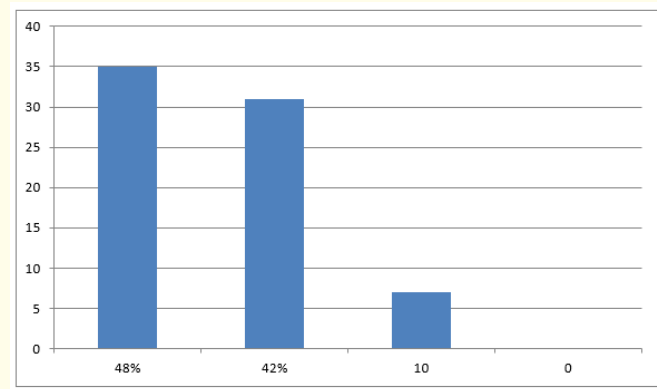

Figure 3: Frequency Distribution of Educational level of respondents.
57

Table 4 show that $53 \%$ of the respondents sells fresh fish where $32 \%$ sells dry fish but $15 \%$ sells both (fresh and dry). This is because the women are one that sells fish to the retailers and consumers and these women called mammy or mongers that see to the selling of fish.

\begin{tabular}{|l|c|c|}
\hline Types of fish marketed & Frequency & Percentage \\
\hline Fresh & 39 & 53 \\
Dry & 23 & 32 \\
Both & 11 & 15 \\
\hline Total & 73 & 100 \\
\hline
\end{tabular}

Table 4: Types of fish form marketed.

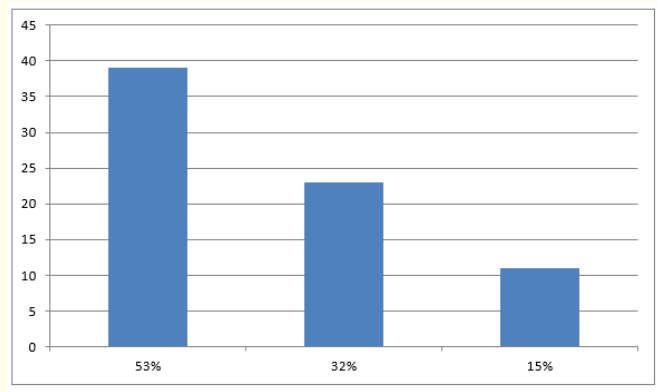

Figure 4: Frequency Distribution of types of fish market.

Table 5 shows that $20 \%$ are into basket making $25 \%$ are evolved in mat making and $24 \%$ are into net making and $41 \%$ are into processing and marketing all this above are part of fishing activities, that are very important in fishing and it also enhance income of the women, Ewuola [9] has suggested to improve the level of rural income is an effort that enhancing more development.

The aim of this study was to examine socio-economic factor and the management practices of fish and the characterizes of women in cooperative societies, was also to determine the extent to which these factors shows the role of women in fishing.

Survey data from seventy three fishing women in Igbokoda local government in Ondo State in Nigeria were used to estimate the result of a given respondents. The study also shows that none of the respondents used modern processing technique and majorly women do all the smoking process to prevent fish from spoiling. 
The Role of Women in Fish Production A Case Study of Igbokoda Local Government Area Ondo State, Nigeria

\begin{tabular}{|l|l|l|l|l|}
\hline Variable & Linear & Exponential & Semi-log & Cobb Douglas \\
\hline Constant term & $6875.28 \times x(21955.46)$ & $10.174(0.705)$ & $0.821(1.967)$ & $11.863(0.050)$ \\
\hline X1 & $93214.14 \times x x(07595.04)$ & $0.392(0.005)$ & $102290.2(22847.87)$ & $0.368(0.050)$ \\
\hline X2 & $0.821(1.967)$ & $5.8 \times 0.57$ & $1580.961(3092.155)$ & $4.005 \times x(0.000)$ \\
\hline X3 & $449.295 \times(269.628)$ & $2.0 \times x x(0.07)$ & $349407.94(16509.67)$ & $9.80 \times x x(0.001)$ \\
\hline X4 & $13865.65(458.578)$ & $9.450 \times x(0.040)$ & $88148.79(28436.84)$ & $4.085 \times x(0.012)$ \\
\hline X5 & $1781.90(19720.76)$ & $0.262(0.069)$ & $-9230.006(23373.24)$ & $-7.6 \times x 0.051$ \\
\hline X6 & $0.988(0.389)$ & $0.123(0.075)$ & $49525.50(31022.47)$ & \\
\hline R2 & 81.3 & 74.1 & 82.8 & 86.0 \\
\hline R2 & 77.1 & 68.3 & 79.0 & 82.9 \\
\hline F & $19.53 \times x x$ & 12.864 & 21.71 & 27.62 \\
\hline
\end{tabular}

Table 5: Result Key.

$\mathrm{X}_{1}=$ Co-operative member

$\mathrm{X}_{2}=$ Income

$\mathrm{X}_{3}=$ Age

$\mathrm{X}_{4}=$ Experience

$\mathrm{X}_{5}=$ Form of Sale

$\mathrm{X}_{6}=$ Expenses

XXX = Significant @ 100

XX = Significant @ 50\%

X= Significant @ 10\%

Figures in parenthesis are standard errors.

\section{Conclusion}

In conclusion it is not an over statement to say that women in fishing production and that women, in fishing also plays a very important role in fishing and also join cooperative society to receive assistance which has made than to be of help to the growth and development of their society. More people (woman) that are involved in fishing industries thereby reducing unemployment.

Also, women should be encouraged by giving them loan and also strengthen the extension capacities. Most of the women need technical support and training programme expansion, available credit facilities to the women to improve the income and living condition of the women in fish production. What a man can do women can do better.

From the table, three variables are significant at $1 \%$ level namely $\left(\mathrm{X}_{1}, \mathrm{X}_{3}, \mathrm{X}_{5}\right)$ variable are also significant at $5 \%$ level $\left(\mathrm{X}_{4}, \mathrm{X}_{6}\right)$ while $\left(\mathrm{X}_{2}\right)$ is variable at $10 \%$.
To measure the explanatory power of the independent variable taken together, the likelihood ratio test was used [10]. The test statistics is likelihood ratio test, where the ratio is the value of the likelihood function assuring a constant probability divided by the value of that function when the probability of entrepreneurs are assumed to depend on the independent variable include. The degree on the freedom is equal to the number of independent variables.

Another criterion used for selecting variables was statistical consideration, given as the ratio of the estimated to their respective standard errors.

Cooperative (X1) from the table has a positive influence on the study which shows that the women in fish cooperative societies has positive influence in the study; this could be due to fact some of the extension agents advice the women to join cooperative society. 
From the table so also Age, income experience, form of sale and expenses $(77 \%, 68 \%, 83 \%$ and $79 \%)$ will cause an increase in the study and role of women in fish production.

\section{Bibliography}

1. F.A.O. Federal Department of Fisheries. Fisheries statics of Nigeria, 5th Edition FEF Abuja Nigeria (1996).

2. FAO. Global Agriculture value increasing 19\% to follow up of Agriculture minutes No 8 in land water Resource and Agriculture service fisheries Development FAO Rome (1995).

3. Tvedten and Hersoug. Gender relations must be central. Given the fact that the persons who inhibit the positions of intermediaries. Centre for marine research 6 (1992): 1-2.

4. Oyegbola O. Role of women in marine and Brackish water artisanal fisheries. A case study of Otutu and Topo fisheries committeesun in Lagos State (2000).

5. Dillion IA and Hardaker 0. "The concept of sustainability origins extensions and usefulness of policy". social Natural Resource 2 (1984): 73-84.

6. Fagbade 0. Role of women in fish market and distribution unpublished thesis University of Ibadan (1992): 7.

7. Amos OT. Women and marketing in Nigeria market paper presented at NIFER Natural workshop on marketing and preservation 16th - 18th (1991): 20.

8. Mogbojuri H O. Fisheries Activities in Ilaje-Ese Odo Local Government Area, Ondo State, Nigeria. A project submitted for the award of Nigeria certificate of Education Adeyemi College of Education Ondo (1987): 1-30.

9. Ewuola SO. Farm credit as a level to Rural Development sustainable Development in Nigeria (1980): 142-146.

10. Nerlove OV And Press T. Evaluation of the economic role of women in fishing cooperation of African (1973): 40-41.

Volume 3 Issue 9 September 2019

(C) All rights are reserved by Sodamola MO., et al. 